\title{
Effects of Process Parameters of Semisolid Stirring on Microstructure of Mg-3Sn-1Mn-3SiC (wt\%) Strip Processed by Rheo-rolling
}

\author{
Zhan-Yong Zhao $^{1} \cdot$ Ren-Guo Guan ${ }^{2} \cdot$ Jian-Hong Zhang ${ }^{1} \cdot$ Zhou-Yang Zhao $^{2} \cdot$ Pei-Kang Bai $^{1}$
}

Received: 28 July 2016/Revised: 13 September 2016/Published online: 31 October 2016

(C) The Chinese Society for Metals and Springer-Verlag Berlin Heidelberg 2016

\begin{abstract}
A novel semisolid stirring and rheo-rolling process for preparing $\mathrm{Mg}-3 \mathrm{Sn}-1 \mathrm{Mn}-3 \mathrm{SiC}$ (wt\%) composite strips was proposed, and the effects of process parameters of semisolid stirring on microstructures of $\mathrm{Mg}-3 \mathrm{Sn}-1 \mathrm{Mn}-3 \mathrm{SiC}$ (wt $\%$ ) composite strips were investigated. The average grain size and roundness decrease, and the distribution of $\mathrm{SiC}$ becomes more homogeneous with the decrease in stirring temperature and the increase in the stirring speed. When the stirring time is increased, the distribution of $\mathrm{SiC}$ particles tends to be homogeneous, and the average grain diameter and roundness of $\alpha$ $\mathrm{Mg}$ grain decrease. Under the following process parameters: the stirring temperature at $640{ }^{\circ} \mathrm{C}$, the stirring speed at $1100 \mathrm{rpm}$, the stirring time at $30 \mathrm{~min}$ and the roll speed at $0.2 \mathrm{~m} / \mathrm{s}, \mathrm{Mg}-3 \mathrm{Sn}-1 \mathrm{Mn}-3 \mathrm{SiC}$ (wt\%) strip with a cross-sectional size of $4 \mathrm{~mm} \times 160 \mathrm{~mm}$ was prepared. The ultimate tensile strength and elongation of $\mathrm{Mg}-3 \mathrm{Sn}-1 \mathrm{Mn}-3 \mathrm{SiC}$ (wt\%) composite strip reached $226 \pm 6 \mathrm{MPa}$ and $(7.4 \pm 0.2) \%$, which are obviously improved in comparison with $\mathrm{Mg}-3 \mathrm{Sn}-1 \mathrm{Mn}$ (wt\%).
\end{abstract}

KEY WORDS: Mg-matrix composite; Rheo-rolling; Microstructure; Property

\section{Introduction}

As a kind of super-light metal material, magnesium alloy is highlighted for its applications in the fields of automobile, electronic products and soon [1]. However, its poor heat resistance and formability limit its wide application [2]. Therefore, to develop high-performance magnesium alloy and advanced processing method has become an important

Available online at http://link.springer.com/journal/40195

Zhan-Yong Zhao

syuzzy@126.com

$\bowtie$ Ren-Guo Guan

guanrg@smm.neu.edu.cn

1 School of Materials Science and Engineering, North University of China, Taiyuan 030051, China

2 School of Materials Science and Engineering, Northeastern University, Shenyang 110819, China subject. Adding micro-alloying elements and preparing Mg-matrix composite material are the main methods to improve the strength and heat resistance of Mg alloys [3]. $\mathrm{Mg}-\mathrm{RE}$ alloys exhibit excellent heat resistance due to the presence of intermetallic with high melting point. But the production cost and price of $\mathrm{Mg}-\mathrm{RE}$ alloy are usually high [4]. Previous research has shown that the addition of $\mathrm{Sn}$ in magnesium alloys led to the formation of thermally stable and high-hardness $\mathrm{Mg}_{2} \mathrm{Sn}$ phases, and thus improved the mechanical properties of $\mathrm{Mg}$ alloys at room and high temperatures [5]. Yang et al. [6] have prepared $\mathrm{Mg}-3 \mathrm{Sn}-$ $2 \mathrm{Ca}$ alloy and found that it has more potential as the elevated temperature magnesium alloy due to its higher creep properties. Nayyeri and Ahmudi [7] have prepared $\mathrm{Mg}-$ $5 \% \mathrm{Sn}-2 \% \mathrm{Ca}$ alloy, which had the low creep rates and the high creep resistance. To improve microstructure and mechanical properties of $\mathrm{Mg}$ alloys, researchers have attempted to develop Mg-matrix composites with nanoparticles such as boron fibers, $\mathrm{B}_{4} \mathrm{C}$ or $\mathrm{SiC}$ particles [8-10]. It was reported that the addition of $\mathrm{SiC}$ particles in 
Mg alloys could obviously improve mechanical properties [10]. Therefore, based on the $\mathrm{Mg}-\mathrm{Sn}$ alloys, preparation of Mg-3Sn-1Mn-3SiC (wt\%) composite attracts more attentions.

Traditional processes for preparing Mg-matrix composite such as stirring casting, squeeze casting, melt infiltration and power metallurgy are usually complex [8, 11-13]. To overcome the above problems, novel semisolid stirring and rheorolling process for preparing $\mathrm{Mg}-3 \mathrm{Sn}-1 \mathrm{Mn}-3 \mathrm{SiC}$ (wt\%) composite strip was proposed. The effects of process parameters on the microstructure of $\mathrm{Mg}-3 \mathrm{Sn}-1 \mathrm{Mn}-3 \mathrm{SiC}$ (wt $\%)$ composite strip were investigated.

\section{Experimental}

The self-designed semisolid stirring device and rheo-rolling experimental apparatus were used in the experiments, as shown in Fig. 1. The roll diameter was $400 \mathrm{~mm}$, and the rolling speed was $0.2 \mathrm{~m} / \mathrm{s}$.

The raw materials were $\mathrm{Mg}-3 \mathrm{Sn}-1 \mathrm{Mn}$ (wt\%) alloy and $\mathrm{SiC}$ particle. The liquidus and solidus temperatures of the alloy are 650 and $625^{\circ} \mathrm{C}$, respectively. The size of the $\mathrm{SiC}$ particles was $30 \mu \mathrm{m}$, and the purity was $98 \%$. To improve the wettability of $\mathrm{SiC}$, the $\mathrm{SiC}$ particles were cleaned by a solution of $1.5 \mathrm{ml} \mathrm{HCl}+100 \mathrm{ml} \mathrm{H}_{2} \mathrm{O}$ for $3 \mathrm{~h}$ and then washed by distilled water. After cleaning $\mathrm{SiC}$ particles were dried at $100{ }^{\circ} \mathrm{C}$ in a drying oven. $\mathrm{Mg}-3 \mathrm{Sn}-1 \mathrm{Mn}$ (wt $\%)$ alloy was melted in a resistance furnace under protection by argon. The melt temperature was held at $720{ }^{\circ} \mathrm{C}$ for $20 \mathrm{~min}$. Hexachloroethane was used for degassing. The activated $\mathrm{SiC}$ was added into the melt by stirring at melt temperature from 630 to $680{ }^{\circ} \mathrm{C}$. The stirring speed varied from 500 to $1100 \mathrm{rpm}$, and the stirring time was set between 3 and $30 \mathrm{~min}$. Subsequently, the $\mathrm{Mg}-$ $3 \mathrm{Sn}-1 \mathrm{Mn}-3 \mathrm{SiC}$ (wt\%) composite slurry was poured onto the surface of the vibrating slope. Finally, semisolid slurry flowed directly into the roll gap, and $\mathrm{Mg}-3 \mathrm{Sn}-1 \mathrm{Mn}-3 \mathrm{SiC}$ (wt\%) composite strips with a cross-sectional size of $4 \mathrm{~mm} \times 160 \mathrm{~mm}$ were prepared by rheo-rolling.

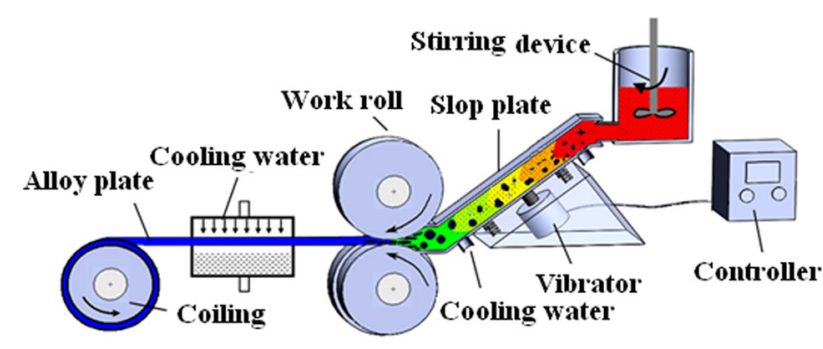

Fig. 1 Schematic diagram of continuous semisolid rolling
Samples from $\mathrm{Mg}-3 \mathrm{Sn}-1 \mathrm{Mn}-3 \mathrm{SiC}$ (wt\%) composite strips prepared under different process parameters were taken. The samples were polished and etched by a solution of $15 \mathrm{ml} \mathrm{HCl}+56 \mathrm{ml} \mathrm{C}_{2} \mathrm{H}_{5} \mathrm{OH}+47 \mathrm{ml} \mathrm{H}_{2} \mathrm{O}$ and then analyzed using scanning electron microscopy (SEM; SSX550, Shimadzu, Kyoto, Japan) and Olympus metallographic microscopy (Olympus; BX51, OLYMPUS, Japan). The average roundness of the grain was calculated by $S_{\mathrm{F}}=\frac{L_{\mathrm{p}}^{2}}{4 \pi A}$, where $S_{\mathrm{F}}$ is the average grain roundness, $L_{\mathrm{p}}$ is total circumference of the measured grains and $A$ is total grain areas. The mechanical properties of the $\mathrm{Mg}-3 \mathrm{Sn}-$ $1 \mathrm{Mn}-3 \mathrm{SiC}$ (wt $\%$ ) composite were measured using a tensile testing machine (ZT-989, Jinan Huaxing Experimental Equipments Co. Ltd., Shandong, China).

\section{Result and Discussion}

\subsection{Influence of Stirring Temperature on the Microstructure of $\mathrm{Mg}-3 \mathrm{Sn}-1 \mathrm{Mn}-3 \mathrm{SiC}$ (wt\%) Composite}

Figure 2 shows a SEM image and EDS of $\mathrm{Mg}-3 \mathrm{Sn}-1 \mathrm{Mn}-$ $3 \mathrm{SiC}(\mathrm{wt} \%)$ composite at stirring temperatures of $680{ }^{\circ} \mathrm{C}$. Figures 3 and 4 show microstructures of $\mathrm{Mg}-3 \mathrm{Sn}-1 \mathrm{Mn}-$ $3 \mathrm{SiC}(\mathrm{wt} \%)$ alloy strips under different stirring temperatures and the relationships among the stirring temperature and $\alpha-\mathrm{Mg}$ grain diameter as well as roundness. The average grain diameter and roundness decrease, and the distribution of $\mathrm{SiC}$ becomes more homogeneous with the decrease in the stirring temperature. When the stirring temperature was $680{ }^{\circ} \mathrm{C}$, the $\mathrm{SiC}$ particles were uneven distribution in the strips, and the pores formed in the agglomeration of particles, as shown in Figs. 2a and 3a. The primary grains were coarse, and the average grain diameter and roundness were $110 \pm 3 \mu \mathrm{m}$ and $4.1 \pm 0.2$, respectively, as shown in Figs. $3 \mathrm{a}$ and 4 . When the stirring temperature decreased to $660{ }^{\circ} \mathrm{C}$, the distribution of $\mathrm{SiC}$ particles was significantly improved, and the average grain diameter and roundness decreased to $102 \pm 3 \mu \mathrm{m}$ and $3.2 \pm 0.2$, respectively, as shown in Figs. $3 \mathrm{~b}$ and 4 . When the stirring temperature decreased further to $640{ }^{\circ} \mathrm{C}$, the distribution of $\mathrm{SiC}$ particles became homogeneous and $\alpha-\mathrm{Mg}$ grain was refined. The average diameter and roundness of grains became $84 \pm 3 \mu \mathrm{m}$ and $2.1 \pm 0.1$, respectively, as shown in Figs. $3 \mathrm{c}$ and 4.

The main reason for this is that solid fraction and the amount of small particles increased with the decrease in the stirring temperature. During stirring process, the shear stress of melt around $\mathrm{SiC}$ particles in $\mathrm{Mg}-3 \mathrm{Sn}-1 \mathrm{Mn}-3 \mathrm{SiC}$ (wt\%) composite can be expressed by the following formula [14], 

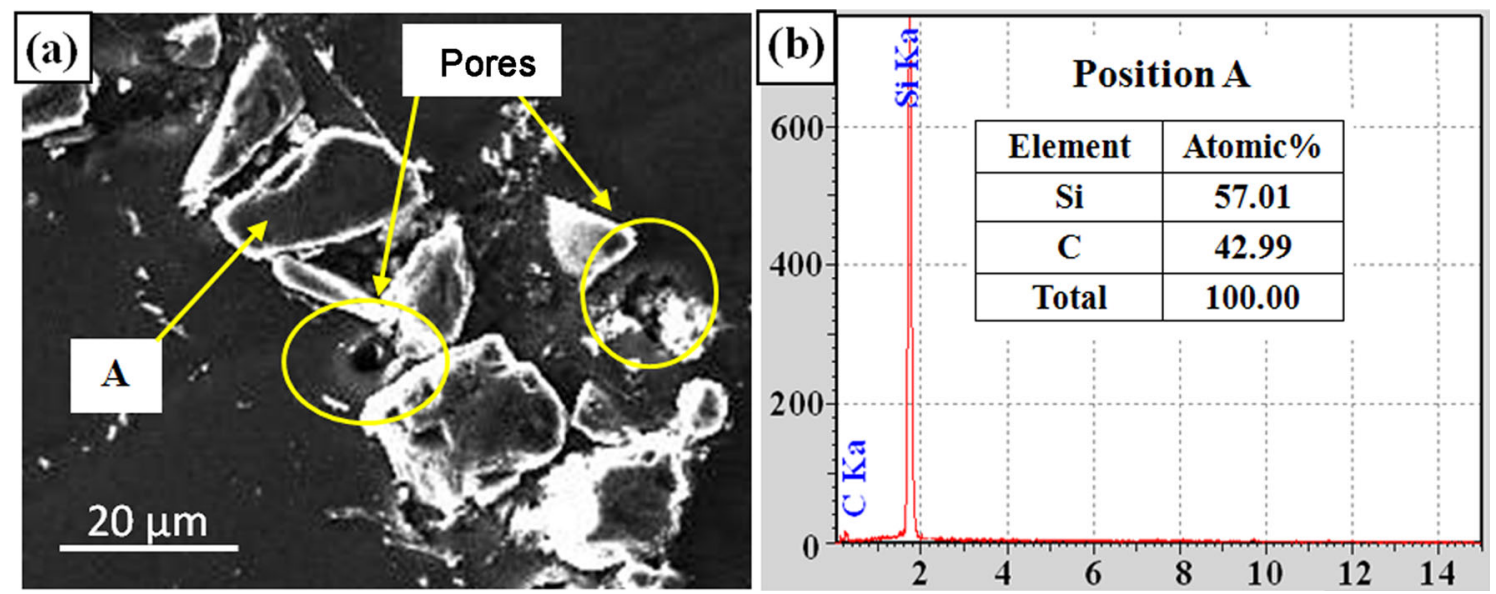

Fig. 2 SEM image a and EDS $\mathbf{b}$ from the position $A$ a of $\mathrm{Mg}-3 \mathrm{Sn}-1 \mathrm{Mn}-3 \mathrm{SiC}\left(\mathrm{wt} \%\right.$ ) composite obtained at stirring temperatures $680{ }^{\circ} \mathrm{C}$ (stirring speeds $800 \mathrm{rpm}$, stirring time $15 \mathrm{~min}$ )

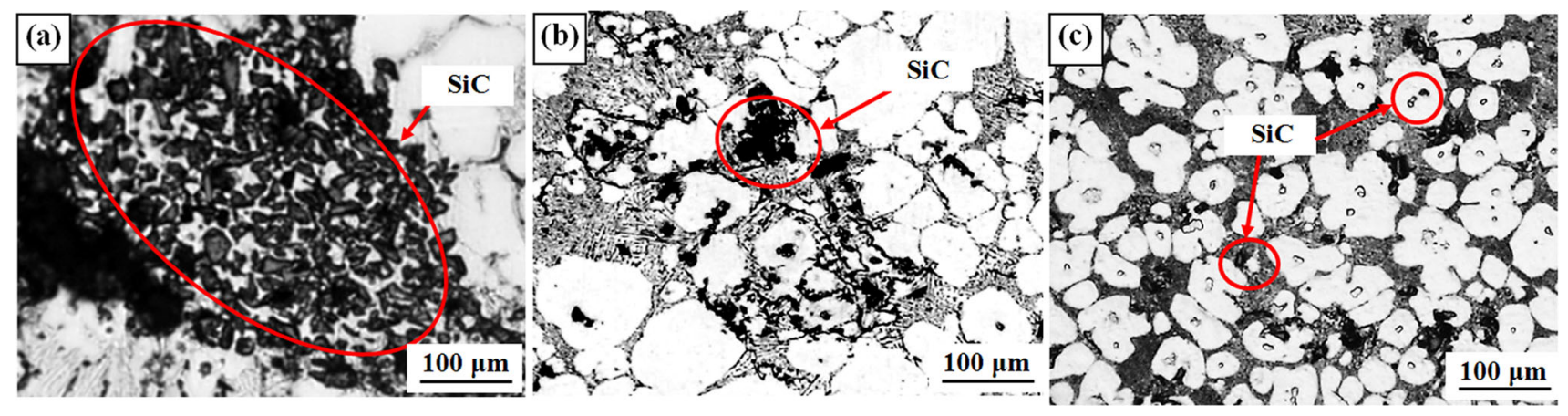

Fig. 3 Microstructures of $\mathrm{Mg}-3 \mathrm{Sn}-1 \mathrm{Mn}-3 \mathrm{SiC}$ (wt\%) composites prepared under different stirring temperatures (stirring speeds $800 \mathrm{rpm}$, stirring time $15 \mathrm{~min}$ ): $\mathbf{a} 680{ }^{\circ} \mathrm{C}, \mathbf{b} 660^{\circ} \mathrm{C}, \mathbf{c} 640^{\circ} \mathrm{C}$

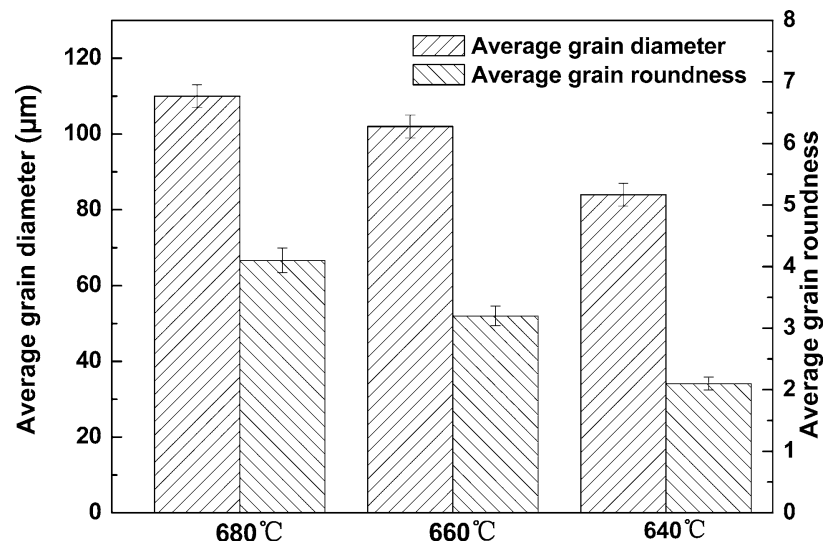

Fig. 4 Average grain diameter and roundness of $\alpha-\mathrm{Mg}$ grain obtained at different stirring temperatures

$\tau_{i j}=-\mu\left[\frac{\partial U_{i}}{\partial x_{j}}+\frac{\partial U_{j}}{\partial x_{i}}\right]$,

where $\tau_{i j}$ is shear stress, $\mu$ is viscosity of alloy melt, and $U$ is spatial coordinates. According to Eq. (1), when the stirring temperature decreased, the solid fraction increased and the shear action of melt was improved, and the wettability and adhesion force between particles and matrix were enhanced. Under the strong collision and friction between the solid particles, the $\mathrm{SiC}$ particles dispersed easily and distributed homogeneously in melt layers. As the solidification microstructure of the alloy is closely related to the nucleation rate of the melt, it was believed that the formation of fine and spherical microstructure is favored by a high nucleation rate. Nucleation in the alloy is closely related to the stirring temperature. Generally, nucleation rate increases with the decrease in the stirring temperature. Therefore, the grain size of the strip also decreases with the decrease in the stirring temperature. At the same time, due to strong shear between different fluid layers, the dendrite breakage and grain boundary melting also caused the grain to be refined and spheroidized.

\subsection{Influence of Stirring Speed \\ on the Microstructure of $\mathrm{Mg}-3 \mathrm{Sn}-1 \mathrm{Mn}-3 \mathrm{SiC}$ (wt\%) Composite}

The distribution of $\mathrm{SiC}$ particles in the composites becomes homogeneous, and the average grain diameter as well as 
roundness of $\alpha-\mathrm{Mg}$ grain decreases with the increase in the stirring speed, as shown in Figs. 5, 6 and 7. When the stirring speed was $500 \mathrm{rpm}, \mathrm{SiC}$ particles distributed unevenly (Fig. 5a), and coarse dendrites occurred (Fig. 6a), the average grain diameter and the roundness of $\alpha-\mathrm{Mg}$ grain were $108 \pm 5 \mu \mathrm{m}$ and $4.8 \pm 0.3$, respectively (Fig. 7). When stirring speed increased to $1100 \mathrm{rpm}$, the distribution of $\mathrm{SiC}$ particles became homogeneous (Fig. 5c), and the microstructure of the strip was mainly composed of spherical grains with the average grain diameter and the roundness of $71 \pm 3 \mu \mathrm{m}$ and $1.6 \pm 0.1$, as shown in Figs. $6 \mathrm{~b}$ and 7.

From Eq. (1), it is can be seen that the shear tress $\tau_{i j}$ of each melt layer is affected by the viscosity of the alloy melt and the velocity of each layers. The shear stress of melt increases with the increase in melt velocity, which is favorable for dendrite breakage and homogeneous distribution of $\mathrm{SiC}$ particles. At the same time, high stirring speed means high-frequency collision and friction between $\mathrm{SiC}$ particles, which is favorable for homogeneous distribution of SiC particles. Mechanical mixing method gains spherical or near spherical primary grain by changing the growth and evolution of the primary crystal metal. The distributions of solute and temperature become more homogeneous with the increase in stirring speed. In this case, when the critical condition for nucleation is satisfied, the uniform solute and temperature distributions can induce eruptive nucleation and lead to high nucleation rate. Shear action also contributed to the formation of near-round $\alpha$ Mg grain.

\subsection{Influence of Stirring Time on the Microstructure of $\mathrm{Mg}-3 \mathrm{Sn}-1 \mathrm{Mn}-3 \mathrm{SiC}$ (wt\%) Composite}

When stirring time increased, the distribution of $\mathrm{SiC}$ particles in $\mathrm{Mg}-3 \mathrm{Sn}-1 \mathrm{Mn}-3 \mathrm{SiC}$ (wt\%) composite tended to be homogeneous, and the average grain diameter and roundness of $\alpha-\mathrm{Mg}$ grain decreased, as shown in Figs. 8 and 9. When the $\mathrm{Mg}-3 \mathrm{Sn}-1 \mathrm{Mn}-3 \mathrm{SiC}$ (wt\%) composite melt was stirred at $1100 \mathrm{rpm}$ for $5 \mathrm{~min}$, the distribution of $\mathrm{SiC}$ particles in composite was unhomogeneous, and the average diameter and roundness of grains were $105 \pm 4 \mu \mathrm{m}$ and $1.8 \pm 0.1$, respectively, as shown in Figs. $8 \mathrm{a}$ and 9. When the stirring time increased to $30 \mathrm{~min}$,
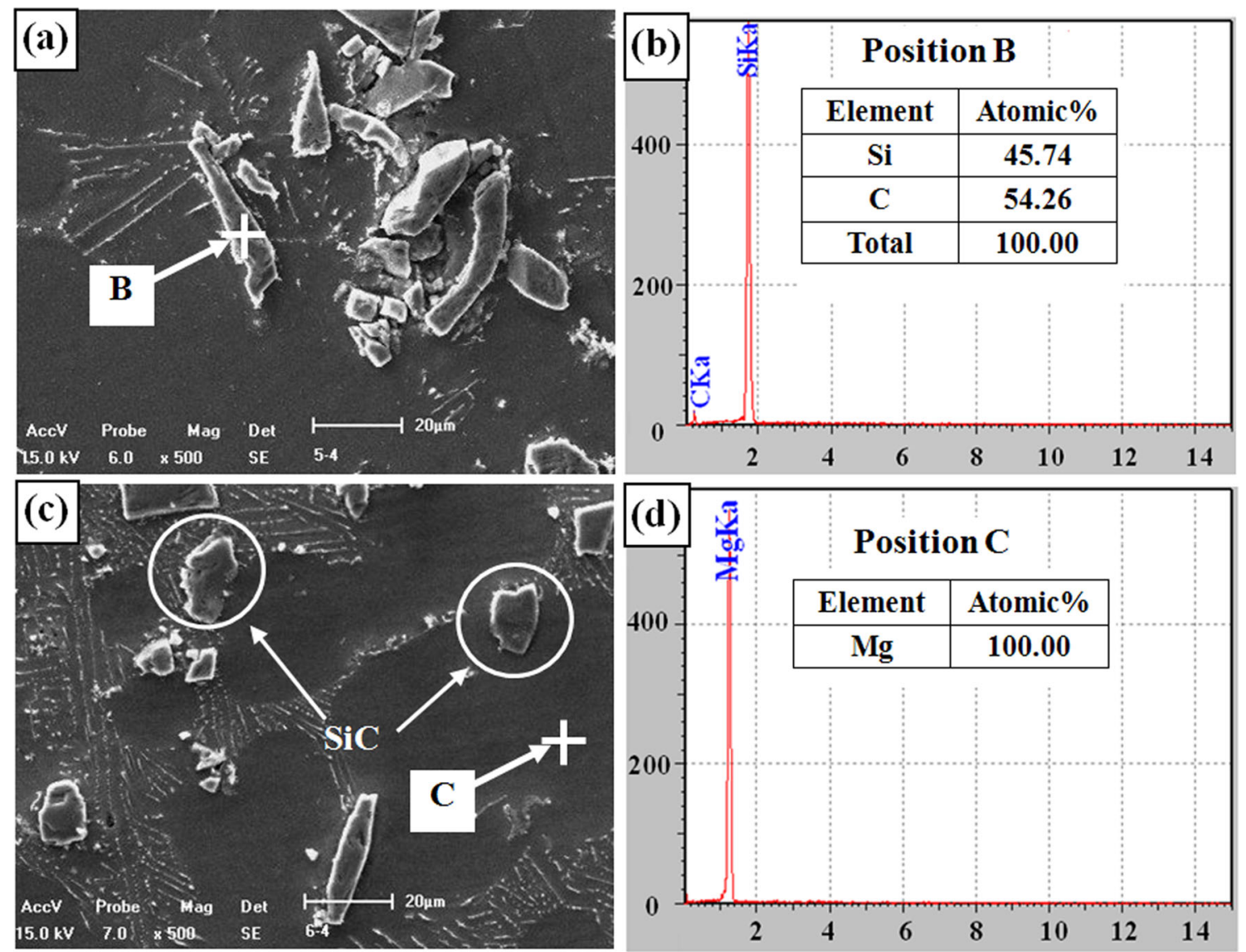

Fig. 5 SEM image and EDS of $\mathrm{Mg}-3 \mathrm{Sn}-1 \mathrm{Mn}-3 \mathrm{SiC}$ (wt\%) composites under different stirring speeds (stirring time was 15 min, and stirring temperature was $640{ }^{\circ} \mathrm{C}$ ): a $500 \mathrm{rpm}$; c $1100 \mathrm{rpm}, \mathrm{EDS}, \mathbf{b}$ from point $B$ a EDS, d from point $C$ c 


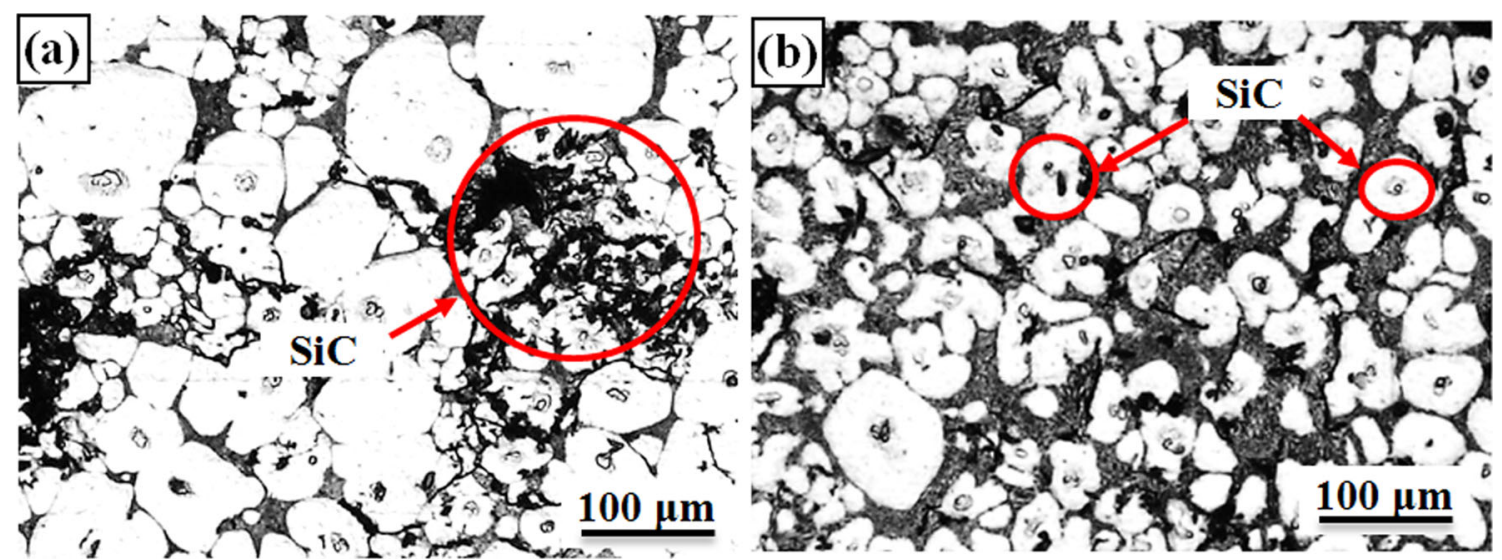

Fig. 6 Microstructures of $\mathrm{Mg}-3 \mathrm{Sn}-1 \mathrm{Mn}-3 \mathrm{SiC}$ (wt $\%$ ) composites under different stirring speeds (stirring time was $15 \mathrm{~min}$, and stirring temperature was $\left.640{ }^{\circ} \mathrm{C}\right)$ : a $500 \mathrm{rpm} ; \mathbf{b} 1100 \mathrm{rpm}$

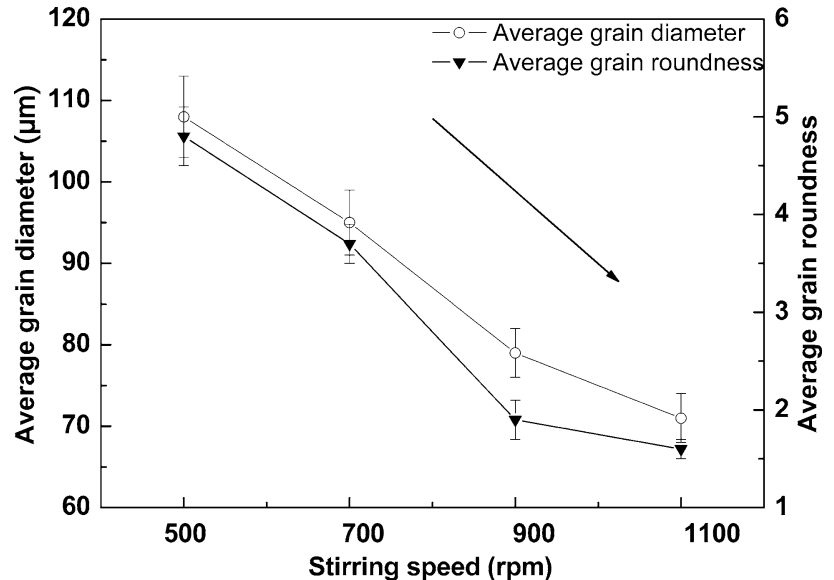

Fig. 7 Relationships among the stirring speed and $\alpha$-Mg grain diameter as well as roundness (stirring time was $15 \mathrm{~min}$, and stirring temperature was $640{ }^{\circ} \mathrm{C}$ )

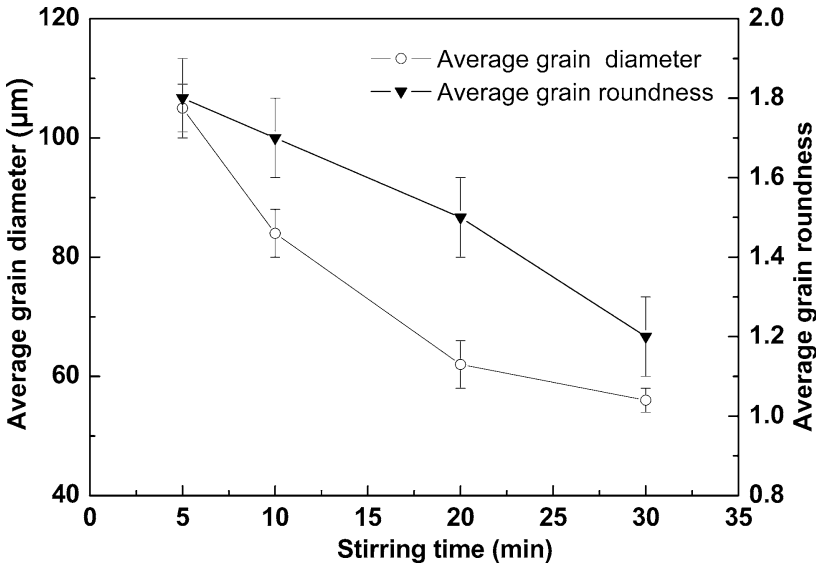

Fig. 9 Relationships among the stirring time and grain diameter as well as roundness

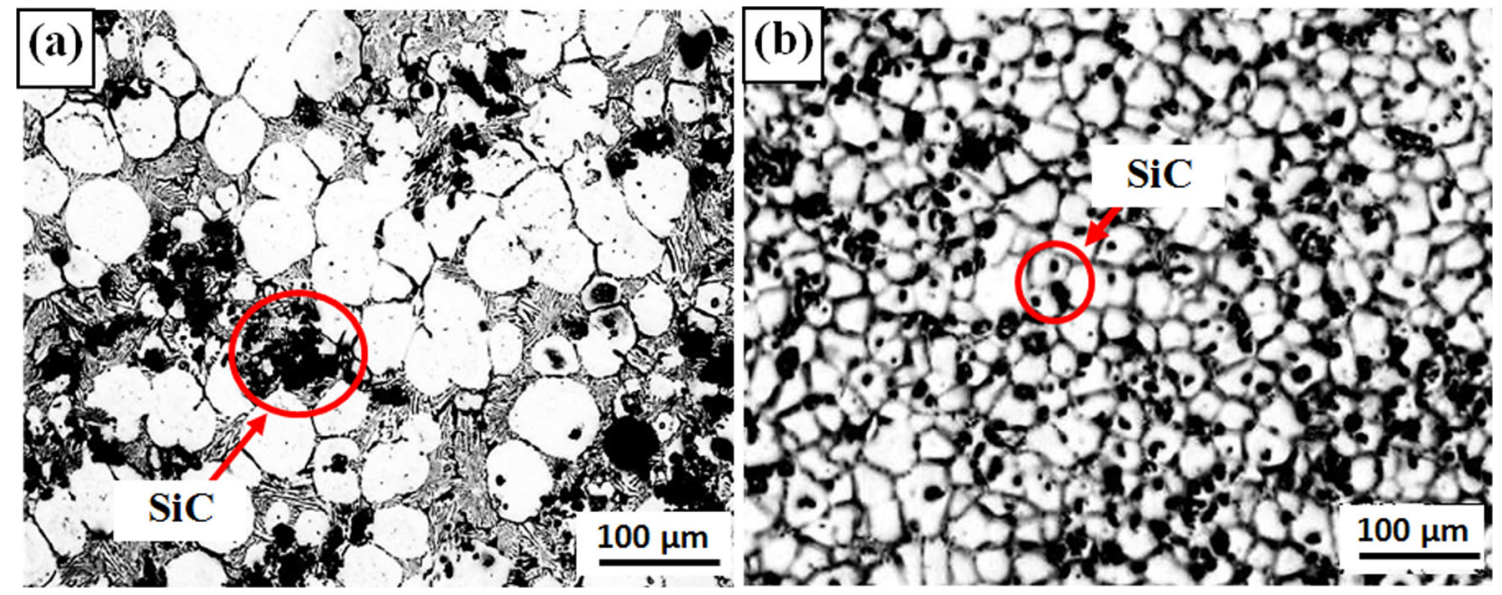

Fig. 8 Microstructures of $\mathrm{Mg}-3 \mathrm{Sn}-1 \mathrm{Mn}-3 \mathrm{SiC}$ (wt $\%$ ) composites under different stirring time (stirring speed at $1100 \mathrm{rpm}$, stirring temperature at $640{ }^{\circ} \mathrm{C}$ ): a $5 \mathrm{~min}$, b $30 \mathrm{~min}$ 
the average diameter and roundness of grains decreased to $56 \pm 2 \mu \mathrm{m}$ and $1.2 \pm 0.1$ (Figs. $8 \mathrm{~b}$ and 9), respectively. Long stirring time is helpful to establishing homogenous solute and temperature fields that are the ideal conditions for nucleation. Moreover, stirring can accelerate the dendrite breakage and heterogonous nucleus liberation, which also causes grain refining. However, if the stirring time was too long, the productivity would be reduced. Therefore, the optimal stirring time of $30 \mathrm{~min}$ is suggested.

\subsection{Microstructure and Properties of Product}

Under the following process parameters: the stirring temperature at $640{ }^{\circ} \mathrm{C}$, the stirring speed at $1100 \mathrm{rpm}$, the stirring time at $30 \mathrm{~min}$, and the roll speed at $0.2 \mathrm{~m} / \mathrm{s}, \mathrm{Mg}_{-}$ $3 \mathrm{Sn}-1 \mathrm{Mn}-3 \mathrm{SiC}$ (wt\%) composite strip with a cross-sectional size of $4 \mathrm{~mm} \times 160 \mathrm{~mm}$ prepared has got a good surface quality and the homogeneous distribution of $\mathrm{SiC}$ particles and the inner microstructure of $\mathrm{Mg}-3 \mathrm{Sn}-1 \mathrm{Mn}-$ $3 \mathrm{SiC}$ (wt $\%$ ) composite strip was mainly composed of fine spherical or rosette grains. The average grain size was $56 \pm 2 \mu \mathrm{m}$, as shown in Fig. 10. The ultimate tensile strength and the elongation of $\mathrm{Mg}-3 \mathrm{Sn}-1 \mathrm{Mn}-3 \mathrm{SiC}$ (wt\%) composite strip were $226 \pm 6 \mathrm{MPa}$ and $(7.4 \pm 0.2) \%$, respectively, as shown in Fig. 11. The ultimate tensile strength and elongation were improved, respectively, by
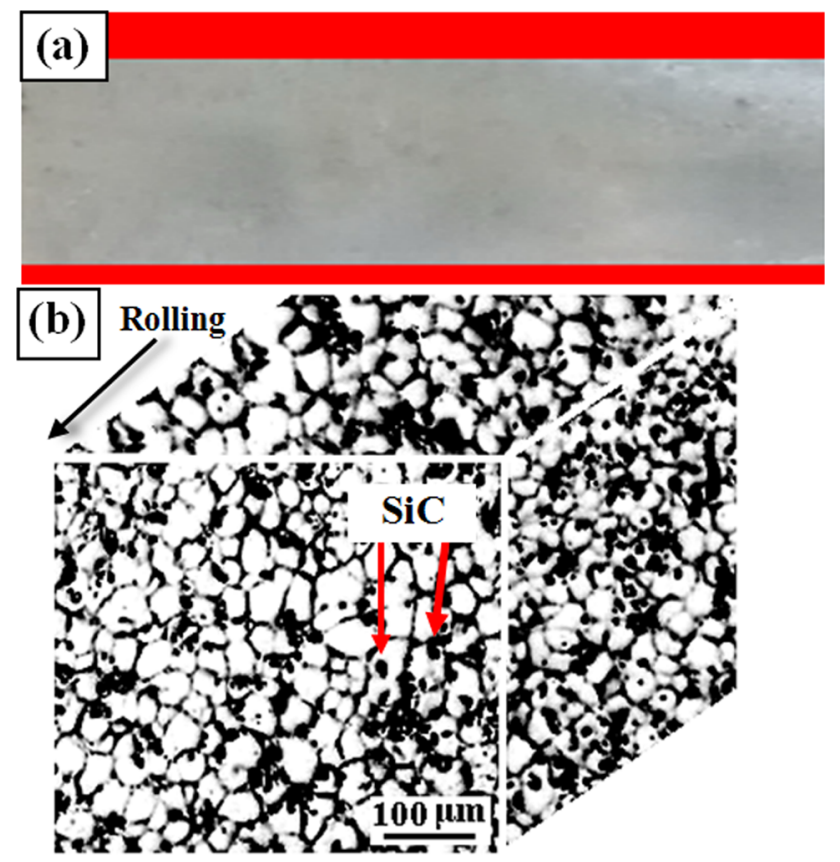

Fig. $10 \mathrm{Mg}-3 \mathrm{Sn}-1 \mathrm{Mn}-3 \mathrm{SiC}(\mathrm{wt} \%)$ composite strip a and its inner microstructures $\mathbf{b}$

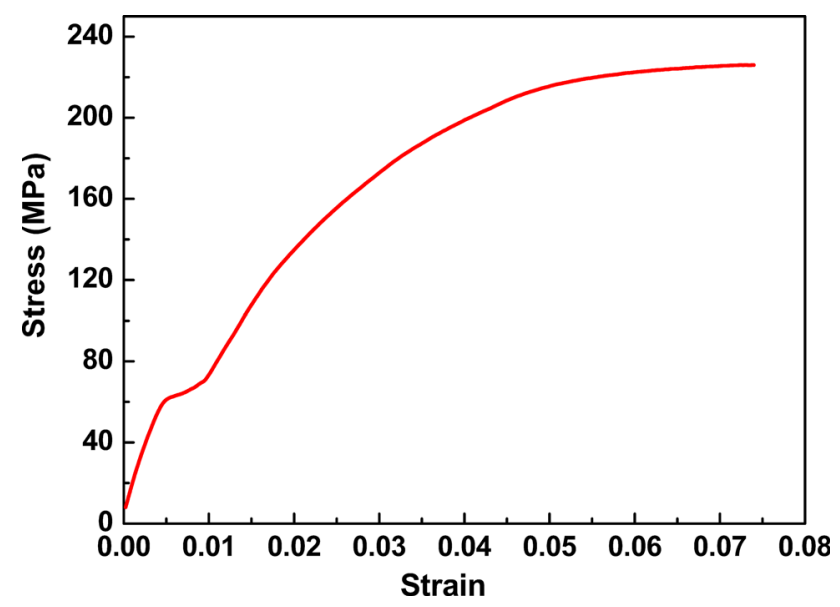

Fig. 11 Engineering stress-strain curve of $\mathrm{Mg}-3 \mathrm{Sn}-1 \mathrm{Mn}-3 \mathrm{SiC}$ (wt\%) composite strip

$(29 \pm 3) \%$ and $(32 \pm 3) \%$ as comparing with those of $\mathrm{Mg}-3 \mathrm{Sn}-1 \mathrm{Mn}$ (wt\%) alloy strip (175 MPa and 5.6\%) [15].

\section{Conclusions}

A novel semisolid stirring and rheo-rolling process for preparing $\mathrm{Mg}-3 \mathrm{Sn}-1 \mathrm{Mn}-3 \mathrm{SiC}$ (wt\%) composite strips was proposed, and the effects of process parameters of the semisolid stirring on microstructures of $\mathrm{Mg}-3 \mathrm{Sn}-1 \mathrm{Mn}-$ $3 \mathrm{SiC}(\mathrm{wt} \%)$ composite strips were investigated. The following conclusions were drawn:

1. The average grain size and roundness decrease, and the distribution of $\mathrm{SiC}$ becomes more homogeneous with the decrease in the stirring temperature.

2. The distribution of $\mathrm{SiC}$ particles is more homogeneous, and the average grain diameter and roundness of $\alpha-\mathrm{Mg}$ grain decrease with the increase in the stirring speed.

3. When the stirring time is increased, the distribution of $\mathrm{SiC}$ particles tends to be homogeneous, and the average grain diameter and roundness of $\alpha-\mathrm{Mg}$ grain decrease.

4. Under the following process parameters: the stirring temperature at $640{ }^{\circ} \mathrm{C}$, the stirring speed at $1100 \mathrm{rpm}$, the stirring time at $30 \mathrm{~min}$ and the roll speed at $0.2 \mathrm{~m} /$ s, Mg-3Sn-1Mn-3SiC (wt\%) composite strip with a cross-sectional size of $4 \mathrm{~mm} \times 160 \mathrm{~mm}$ was prepared. The ultimate tensile strength and elongation of $\mathrm{Mg}-$ 3Sn-1Mn-3SiC (wt\%) composite strip reach $226 \pm 6 \mathrm{MPa}$ and $(7.4 \pm 0.2) \%$, which are obviously improved in comparison with those of $\mathrm{Mg}-3 \mathrm{Sn}-1 \mathrm{Mn}$ (wt\%). 
Acknowledgements This work was financially supported by The National Natural Science Foundation of China (Nos. 51604246 and 51674077) and Shanxi Province Science Foundation for Youths.

\section{References}

[1] S. Chen, L. Zheng, S. Zhang, H. Song, M. Cheng, Acta Metall. Sin. (Engl. Lett.) 28, 1426 (2015)

[2] Q. Liu, Acta Metall. Sin. (in Chinese) 46, 1458 (2010)

[3] K. Suresh, K.P. Rao, Y.V.R.K. Prasad, N. Hort, K.U. Kainer, Trans. Nonferrous Met. Soc. China 60, 637 (2014)

[4] J. Kubasek, D. Vojtecn, Trans. Nonferrous Met. Soc. China 23, 1215 (2013)

[5] Z. Shi, J. Alloys Compd. 559, 158 (2013)

[6] M. Yang, L. Cheng, F. Pan, Trans. Nonferrous Met. Soc. China 20, 584 (2010)
[7] G. Nayeri, R. Ahmudi, Mater. Sci. Eng. A 527, 2087 (2010)

[8] A. Shaga, P. Shen, C. Sun, Q. Jiang, Mater. Sci. Eng. A 630, 78 (2015)

[9] H. Zhang, G. Chen, R. Pei, D. Li, Mater. Sci. Eng. A 613, 111 (2014)

[10] S. Sankaranarayana, R.K. Sabat, S. Jayalakshmi, S. Suwas, M. Gupta, Mater. Chem. Phys. 143, 1178 (2014)

[11] W. Du, Z. Yan, Y. Wu, Z. Wang, T. Zuo, Rare Met. Mater. Eng. 38, 559 (2009)

[12] K.K. Deng, X.J. Wang, M.Y. Zheng, K. Wu, Mater. Sci. Eng. A 560, 824 (2013)

[13] X.J. Wang, X.S. Hu, Y.Q. Wang, K.B. Nie, K. Wu, M.Y. Zhang, Mater. Sci. Eng. A 559, 139 (2013)

[14] Z.Y. Zhao, R.G. Guan, H.Q. Huan, F.R. Cao, C.G. Dai, Chin. J. Nonferrous Met. 21, 2043 (2011)

[15] R.G. Guan, Z.Y. Zhao, H. Zhang, C. Lian, C.S. Lee, C.M. Liu, J. Mater. Process. Technol. 212, 1430 (2012) 